\title{
Endolymph Composition: Paradigm or Inevitability?
}

\author{
H. GAGOV ${ }^{1}$, M. CHICHOVA ${ }^{1}$, M. MLADENOV ${ }^{2}$ \\ ${ }^{1}$ Faculty of Biology, Sofia University St. Kliment Ohridski, Sofia, Bulgaria, ${ }^{2}$ Institute of Biology, \\ Faculty of Natural Sciences and Mathematics, University of Skopje Sts. Cyril and Methodius, \\ Skopje, Macedonia
}

Received June 1, 2017

Accepted August 24, 2017

On-line January 5, 2018

\section{Summary}

This review is focused on the unusual composition of the endolymph of the inner ear and its function in mechanoelectrical transduction. The role of $\mathrm{K}^{+}$and $\mathrm{Ca}^{2+}$ in excitatory influx, the very low $\mathrm{Na}^{+}, \mathrm{Ca}^{2+}$ and $\mathrm{Mg}^{2+}$ concentrations of endolymph, stereocilia structure of hair cells and some proteins involved in mechanosensory signal transduction with emphasis on auditory receptors are presented and analyzed in more details. An alternative hypothetical model of ciliary structure and endolymph with a 'normal' composition is discussed. It is concluded that the unique endolymph cation content is more than an energy saving mechanism that avoids disturbing circulatory vibrations to achieve a much better mechanosensory resolution. It is the only possible way to fulfil the requirements for a precise ciliary mechanoelectrical transduction in conditions where pressure events with quite diverse amplitudes and duration are transformed into adequate hair cell membrane depolarizations, which are regulated by a sensitive $\mathrm{Ca}^{2+}$-dependent feedback tuning.

\section{Key words}

Hair cells $\bullet \mathrm{K}^{+}$influx $\bullet$ Mechanosensing $\bullet$ Mitochondria

\section{Corresponding author}

H. Gagov, Faculty of Biology, Sofia University St. Kliment Ohridski, 8 Dragan Tzankov blvd. 8, Sofia, 1164 Bulgaria. E-mail: hgagov@abv.bg

\section{Composition of endolymph of the inner ear}

Mechanical sensor cells of the cochlear and vestibular receptor organ are called hair cells (HC) because of the presence of stereocilia. These stereocilia are bathed in high $\mathrm{K}^{+}$, low $\mathrm{Na}^{+}, \mathrm{Mg}^{2+}, \mathrm{Ca}^{2+}$ and a proteincontaining solution called endolymph. The cochlea of the inner ear has two types of receptor cells - outer and inner auditory $\mathrm{HC}$ depending on their position in the organ of Corti. The intima mechanosensing mechanism of the auditory signal transduction in $\mathrm{HC}$ has been intensively studied and exhaustively reviewed (Fettiplace and Hackney 2006, Nin et al. 2016, Wangemann 2006, Zdebik et al. 2009). To a great extent the transduction of mechanical stimuli into membrane depolarization, mediator secretion and action potential generation in auditory or vestibular afferent sensory neurons are clear (Fettiplace and Hackney 2006, Wangemann 2006). However, one important detail of the transduction mechanism, the unique endolymph ion content, is not completely explained. Concentrations of about $157 \mathrm{mmol} / 1 \mathrm{~K}^{+}, 1 \mathrm{mmol} / 1 \mathrm{Na}^{+}, 0.02 \mathrm{mmol} / 1$ free $\mathrm{Ca}^{2+}$ and $0.01 \mathrm{mmol} / \mathrm{l} \mathrm{Mg}^{2+}$ (Bosher and Warren 1978, Scheibe et al. 1999, Wangemann 2006) are really exceptional for extracellular body fluid. The differences of mammalian endolymph cation content versus perilymph, blood plasma and other common extracellular solutions varies between about 30 times higher for $\mathrm{K}^{+},>60$ times lower for free $\mathrm{Ca}^{2+}$ and $\mathrm{Mg}^{2+}$, and $>100$ times lower for $\mathrm{Na}^{+}$. 


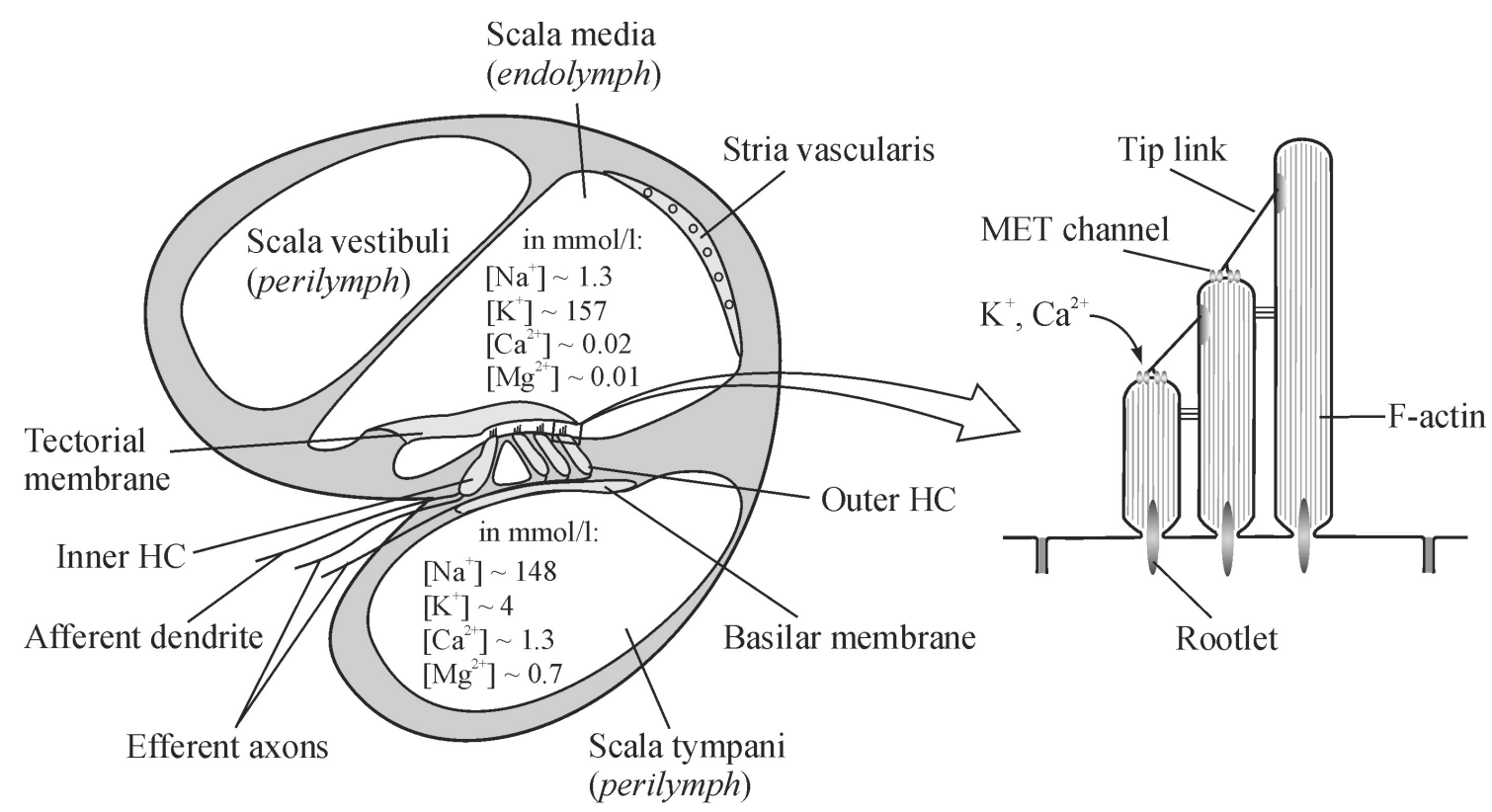

Fig. 1. Compartments of cochlea with organ of Corti and stereochilia basic structure. Endolymph fills scala media and perilymph fills scala vestibule and scala tympani. The corresponding concentrations of inorganic cations in mammals are presented. MET, mechanoelectrical transduction. Data for the cations content are from Scheibe et al. (1999) and Wangemann (2006).

\section{Excitatory $\mathrm{K}^{+}$and $\mathrm{Ca}^{2+}$ influx: mechanical, spatial and metabolic considerations}

The excitation of neurons, muscle and receptor cells depends mainly on $\mathrm{Na}^{+}$influx, in primarily through voltage-dependent $\mathrm{Na}^{+}$channels (Moczydlowski 2012a), ionotropic receptors (Moczydlowski 2012b) and cAMP or cGMP gated channels (Connors 2012). The influx of $\mathrm{Na}^{+}$transiently depolarizes cell membranes and thus generates nonregenerative and graded receptor potentials in the sensory part of sensory neurons and in receptor cells, or elicits an all-or-nothing response-action potential in axons and skeletal muscle cells (Moczydlowski 2012a,b). This mechanism seems to be suitable also for $\mathrm{HC}$ but surprisingly $\mathrm{K}^{+}$influx is the way for depolarization of their ciliary membranes (Fettiplace and Hackney 2006) that is followed by the secretion of glutamate for afferent auditory sensory neurons (Ottersen et al. 1998). An indication of the reason of this phenomenon is the fact that the only part of the $\mathrm{HC}$ in contact with the endolymph are stereocilia (Fig. 1). Endolymph is produced in the stria vascularis of the lateral cochlear wall (Uetsuka et al. 2015, Zdebik et al. 2009), i.e. outside the mechanical signal transduction area of the inner ear. It was stated that the reason for its high $\mathrm{K}^{+}$and low $\mathrm{Na}^{+}$content is to decrease the energy requirements of inner and outer hair cells, and thus of the organ of Corti as a whole (Zdebik et al. 2009). Using $\mathrm{K}^{+}$ and $\mathrm{Ca}^{2+}$ influx instead of $\mathrm{Na}^{+}$for ciliary membrane depolarization avoids the need for many high ATP-consuming $\mathrm{Na}^{+} / \mathrm{K}^{+}$pumps there. Cell membranes possess millions of these ion transporters that utilize around one third of the body energy (Simmers 2012) and up to $66-70 \%$ of the neuronal ATP (Howarth et al. 2012, Simmers 2012). On the other side $\mathrm{K}^{+}$influx only slightly increased high $\mathrm{K}^{+}$concentration of ciliary cytoplasm. $\mathrm{K}^{+}$homeostasis of $\mathrm{HC}$ is sparingly achieved by opening of $\mathrm{K}^{+}$channels outside the ciliary region (Connors 2012). As a consequence, vascularization of the mechanosensory area is more distant (Shi 2011) and in this way the mechanical influence of closely situated microcirculatory vessels is prevented (Zdebik et al. 2009). However, there are additional undervalued considerations for the formation of such exceptional body fluid. In the first place this is the low diffusion rate of ions between ciliary space and cell bulk. A clear sign for restricted diffusion between ciliary and $\mathrm{HC}$ body cytoplasm is the very low free $\mathrm{Ca}^{2+}$ concentration in endolymph (Bosher and Warren 1978, Wangemann 2006), as well as the many molecules of isoform 2 of plasma membrane $\mathrm{Ca}^{2+}$-ATPase (PMCA2), present in the ciliary membrane with density of about $2,200 / \mu \mathrm{m}^{2}$ (Chen et al. 2012). The limited ability of PMCA2 to extrude ciliary $\mathrm{Ca}^{2+}$ 'may constitute a major cause of outer $\mathrm{HC}$ vulnerability and high-frequency hearing loss' (Chen et al. 2012). Significant $\mathrm{Ca}^{2+}$ influx through the mechanoelectrical transduction channel complex containing transmembrane channel-like 1 and 2 as its essential components (Kurima 
et al. 2015) is sufficient to saturate ciliary cytoplasm and to induce $\mathrm{Ca}^{2+}$-dependent sensitization of these channels despite PMCA2 and the abundant presence of $\mathrm{Ca}^{2+}$ buffer proteins there (Hackney et al. 2005). The diffusion between cilia and $\mathrm{HC}$ body is troubled not only by its tiny ankle base but also by the presence of a rootlet inside it. This rootlet represents a protein dense bundle comprised mainly of $\beta$ - and $\gamma$-actin, but also of spectrin, tropomyosin and TRIOBP, a cytoskeleton-associated protein, which extends with similar length in cilia and cell body, and fulfils the significant part of the section of their connection (Fettiplace and Hackney 2006, Furness et al. 2008, Kitajiri et al. 2010). As a result, the diffusion between these well distinguishable $\mathrm{HC}$ parts is reduced. In this way the ATP movement towards cilia and ADP backwards to $\mathrm{HC}$ body is restricted. Therefore, mitochondria in $\mathrm{HC}$ body will not be able to provide sufficient ATP to support energy consumption of many $\mathrm{Na}^{+} / \mathrm{K}^{+}$pumps, together with a significant number of PMCA and other ciliary ATPases. Another reason for $\mathrm{K}^{+}$instead of $\mathrm{Na}^{+}$influx is the fact that mechanoelectrical transduction in the restricted ciliary space would not be troubled by the moderate increase of intraciliar $\mathrm{K}^{+}$as it would only barely influence the reversal potential of $\mathrm{K}^{+}$ due to the high potassium concentration in the cytoplasm.

An alternative hypothetical way to ensure ciliary $\mathrm{HC}$ metabolic requirements if $\mathrm{Na}^{+}$depolarization occurs is to place mitochondria directly into stereocilia. This way, problems with ATP and ion diffusion limitation would be solved, but several others would arise. First, the need of intense vascularization that will generate continuous micro mechanical vibrations and thus a much lower signal/noise ratio of the sensor (Zdebik et al. 2009). Second, the average mitochondrial size - about 0.25-0.5 $\mu \mathrm{m}$ wide and 1-2 $\mu \mathrm{m}$ or more in length, and a volume range from a few thousandths of $\mu \mathrm{m}^{3}$ to a several $\mu \mathrm{m}^{3}$ (Kayar et al. 1988) are comparable with the dimensions of the entire stereocilium as the diameter of the tallest auditory stereocilium is about $0.25 \mu \mathrm{m}$ and the height varies from $1 \mu \mathrm{m}$ (calculated volume $\sim 0.05 \mu \mathrm{m}^{3}$ ) to $6 \mu \mathrm{m}$ (calculated volume $\sim 0.3 \mu \mathrm{m}^{3}$ ) depending on the location (Lim 1980). The presence of mitochondria will harm the mechanical sensitivity due to an improper ciliary architecture caused by the reduction of their abundant core of filaments (mainly actin, Slepecky and Chamberlain 1985), which should be replaced by mitochondria. Additionally, the absence of mitochondria in the ciliary area (Furness et al. 2008, Sipe et al. 2013, Bullen et al. 2015), decreases the probability of oxidative stress damage of $\mathrm{HC}$ because they are a main cellular source of reactive oxygen species (Murphy 2009). This influence is vulnerable even under ambient noise conditions while recurrent oxidative stress significantly enhances $\mathrm{HC}$ death (Baker and Staecker 2012, Nuttall et al. 2016). An impaired $\mathrm{Ca}^{2+}$ buffering is also expected due to the mitochondrial $\mathrm{Ca}^{2+}$-buffer capacity (Williams et al. 2013) that ultimately will spoil the precise $\mathrm{Ca}^{2+}$-dependent regulation of the mechanosensory channel complex (Kurima et al. 2015) by abundant ciliary $\mathrm{Ca}^{2+}$-binding proteins (Hackney et al. 2005). Therefore, the unusual endolymph content is the only possible way to avoid the mitochondrial presence in the $\mathrm{HC}$ mechanosensing area, which ensures adequate ciliary elasticity, a proper and sustained working mode of mechanoelectrical transduction and its precise $\mathrm{Ca}^{2+}$-dependent regulation.

The risk of $\mathrm{Ca}^{2+}$ overload in the ciliary area exists due to a basic characteristics of the mechanotransducer channel - a very large single channel conductance in the range of 100-320 mS, depending on the species, type of sensory HC (outer, inner), as well as their location on the top of stereocilia and high $\mathrm{Ca}^{2+}$ selectivity (Beurg et al. 2006). The last specificity is overcome by another special feature of mammalian endolymph - very low concentration of free $\mathrm{Ca}^{2+}-$ $0.02 \mathrm{mmol} / 1$ vs. about $1.2 \mathrm{mmol} / 1$ in the other extracellular body fluids (Wangemann 2006). The combination of low extracellular free $\mathrm{Ca}^{2+}$ and abundant $\mathrm{Ca}^{2+}$ binding proteins in ciliary cytoplasm forms the optimal $\mathrm{Ca}^{2+}$ influx/ciliary free $\mathrm{Ca}^{2+}$ ratio for a precise regulation of the mechanotranducer channel complex conductivity during continuous auditory stimulation by a variety of pressure amplitudes.

$\mathrm{Mg}^{2+}$ concentration of mammalian endolymph is also very low (about $0.01 \mathrm{mM}$, Bosher and Warren 1978). This is needed to avoid $\mathrm{Mg}^{2+}$-dependent reduction of the ciliary inward current and the prolonging of its time constant of adaptation (Ricci and Fettiplace 1998), i.e. the low amount of this bivalent cation is necessary for optimal gating and kinetic properties of ciliary mechanosensory channels.

In conclusion the unique endolymph $\mathrm{K}^{+}, \mathrm{Na}^{+}$, $\mathrm{Ca}^{2+}$ and $\mathrm{Mg}^{2+}$ content is more than an energy saving mechanism that avoids disturbing circulatory vibrations to achieve a much better mechanosensory resolution. It is the only possible way to fulfil the requirements for a precise ciliary mechanoelectrical transduction in conditions where the pressure events with quite diverse amplitudes and duration are transformed into adequate 
HC membrane depolarizations, which are regulated by a sensitive $\mathrm{Ca}^{2+}$-dependent feedback tuning. No doubt, the cochlear mechanosensing is a wondrous phenomenon and the endolymph is one of its major and unavoidable components.

\section{Conflict of Interest}

There is no conflict of interest.

\section{Acknowledgements}

This study was supported by Grant No 80-10-17/2017 from the Sofia University 'St. Kliment Ohridski'.

\section{References}

BAKER K, STAECKER H: Low dose oxidative stress induces mitochondrial damage in hair hells. Anat Rec 295: 1868-1876, 2012.

BEURG M, MICHAEL G, EVANS MG, CAROLE M, HACKNEY CM, FETTIPLACE R: A large-conductance calcium-selective mechanotransducer channel in mammalian cochlear hair cells. J Neurosci 26: 10992-11000, 2006.

BOSHER SK, WARREN RL: Very low calcium content of cochlear endolymph, an extracellular fluid. Nature 273: 377-378, 1978.

BULLEN A, WEST T, MOORES C, ASHMORE J, FLECK RA, MACLELLAN-GIBSON K, FORGE A: Association of intracellular and synaptic organization in cochlear inner hair cells revealed by $3 \mathrm{D}$ electron microscopy. $J$ Cell Sci 128: 2529-2540, 2015.

CHEN Q, MAHENDRASINGAM S, TICKLE JA, HACKNEY CM, FURNESS DN, FETTIPLACE R: The development, distribution and density of the plasma membrane calcium ATPase 2 calcium pump in rat cochlear hair cells. Eur J Neurosci 36: 2302-2310, 2012.

CONNORS BW: Sensory transduction. In: Medical Physiology: a Cellular and Molecular Approach. 2nd ed., WF BORON, EL BOULPAEP (eds), Philadelphia, Saunders, 2012, pp 371-407.

FETTIPLACE R, HACKNEY CM: The sensory and motor roles of auditory hair cells. Nat Rev Neurosci 7: 19-29, 2006.

FURNESS DN, MAHENDRASINGAM S, OHASHI M, FETTIPLACE R, HACKNEY CM: The dimensions and composition of stereociliary rootlets in mammalian cochlear hair cells: comparison between high- and low-frequency cells and evidence for a connection to the lateral membrane. J Neurosci 28: 6342-6353, 2008.

HACKNEY CM, MAHENDRASINGAM S, PENN A, FETTIPLACE R: The concentrations of calcium buffering proteins in mammalian cochlear hair cells. J Neurosci 25: 7867-7875, 2005.

HOWARTH C, GLEESON P, ATTWELL D: Updated energy budgets for neural computation in the neocortex and cerebellum. J Cereb Blood Flow Metab 32: 1222-1232, 2012.

KAYAR SR, HOPPELER H, MERMOD L, WEIBEL ER: Mitochondrial size and shape in equine skeletal muscle: a three-dimensional reconstruction study. Anat Rec 222: 333-339, 1988.

KITAJIRI S, SAKAMOTO T, BELYANTSEVA IA, GOODYEAR RJ, STEPANYAN R, FUJIWARA I, BIRD JE, RIAZUDDIN S, RIAZUDDIN S, AHMED ZM, HINSHAW JE, SELLERS J, BARTLES JR, HAMMER JA 3RD, RICHARDSON GP, GRIFFITH AJ, FROLENKOV GI, FRIEDMAN TB: Actin-bundling protein TRIOBP forms resilient rootlets of hair cell stereocilia essential for hearing. Cell 141: 786-798, 2010.

KURIMA K, EBRAHIM S, PAN B, SEDLACEK M, SENGUPTA P, MILLIS BA, CUI R, NAKANISHI H, FUJIKAWA T, KAWASHIMA Y, CHOI BY, MONAHAN K, HOLT JR, GRIFFITH AJ, KACHAR B: TMC1 and TMC2 localize at the site of mechanotransduction in mammalian inner ear hair cell stereocilia. Cell Rep 12: 1606-1617, 2015.

LIM DJ: Cochlear anatomy related to cochlear micromechanics. A review. J Acoust Soc Am 67: 1686-1695, 1980.

MOCZYDLOWSKI EG: Electrical excitability and action potentials. In: Medical Physiology: a Cellular and Molecular Approach. 2nd ed., WF BORON, EL BOULPAEP (eds), Philadelphia, Saunders, 2012a, pp 192-194.

MOCZYDLOWSKI EG: Synaptic transmission and the neuromuscular junction. In: Medical Physiology: a Cellular and Molecular Approach. 2nd ed., WF BORON, EL BOULPAEP (eds), Philadelphia, Saunders, 2012b, pp 217-220. 
MURPHY MP: How mitochondria produce reactive oxygen species. Biochem J 417: 1-13, 2009.

NIN F, YOSHIDA T, SAWAMURA S, OGATA G, OTA T, HIGUCHI T, MURAKAMI S, DOI K, KURACHI Y, HIBINO H: The unique electrical properties in an extracellular fluid of the mammalian cochlea; their functional roles, homeostatic processes and pathological significance. Pflugers Arch 468: 1637-1649, 2016.

NUTTALL AL, FOSTER S, ZHANG Y, WILSON T: Mitochondrial dynamics in auditory sensory cells. FASEB J 30: 1015.4, 2016.

OTTERSEN OP, TAKUMI Y, MATSUBARA A, LANDSEND AS, LAAKE JH, USAMI S: Molecular organization of a type of peripheral glutamate synapse: the afferent synapses of hair cells in the inner ear. Prog Neurobiol 54: 127-148, 1998.

RICCI AJ, FETTIPLACE R: Calcium permeation of the turtle hair cell mechanotransducer channel and its relation to the composition of endolymph. J Physiol 506: 159-173, 1998.

SCHEIBE F, HAUPT H, ISING H: Total magnesium concentrations of perilymph, cerebrospinal fluid and blood in guinea pigs fed different magnesium-containing diets. Eur Arch Otorhinolaryngol 256: 215-219, 1999.

SHI X: Physiopathology of the cochlear microcirculation. Hear Res 282: 10-24, 2011.

SIMMERS J: Motor control: learning new moves with old pumps. Curr Biol 22: R194-R196, 2012.

SIPE CW, LIU L, LEE L, GRIMSLEY-MYERS C, LU X: Lis1 mediates planar polarity of auditory hair cells through regulation of microtubule organization. Development 140: 1785-1795, 2013.

SLEPECKY N, CHAMBERLAIN SC: Immunoelectron microscopic and immunofluorescent localization of cytoskeletal and muscle-like contractile proteins in inner ear sensory hair cells. Hear Res 20: 245-260, 1985.

UETSUKA S, OGATA G, NAGAMORI S, ISOZUMI N, NIN F, YOSHIDA T, KOMUNE S, KITAHARA T, KIKKAWA Y, INOHARA H: Molecular architecture of the stria vascularis membrane transport system, which is essential for physiological functions of the mammalian cochlea. Eur J Neurosci 42: 1984-2002, 2015.

WANGEMANN P: Supporting sensory transduction: cochlear fluid homeostasis and the endocochlear potential. J Physiol 576: 11-21, 2006.

WILLIAMS GSB, BOYMAN L, CHIKANDO AC, KHAIRALLAH RJ, LEDERER WJ: Mitochondrial calcium uptake. PNAS 110: 10479-10486, 2013.

ZDEBIK AA, WANGEMANN P, JENTSCH TJ: Potassium ion movement in the inner ear: Insights from genetic disease and mouse models. Physiology 24: 307-316, 2009. 